\title{
Research on the Reform of Practical Teaching System of Economics and Management Majors in Universities*
}

\author{
Hang Gao \\ Business School \\ Shandong University of Political Science and Law \\ Ji'nan, China
}

\begin{abstract}
The economic and social development of China has entered a new era, which also poses new challenges to the quality of university talent training. Economics and management majors are the majors most closely related to economic and social development. Only by innovating the training mode and teaching system of economics and management majors can universities adapt to the requirements of new social and economic environment for talents. In the context of the popularization of higher education in China, universities should promote the reform of practical teaching system of economics and management majors, starting from the urgent demand of the market for applied talents and taking the cultivation of innovation and entrepreneurship ability as the orientation. To be specific, the reform of practical teaching system of economics and management majors should be realized by optimizing the setting of practical curriculum system, creating multi-level and three-dimensional practical courses, enriching experimental teaching resources, building a teaching platform combining school and enterprises, and strengthening teaching management and guarantee.
\end{abstract}

Keywords-economics and management majors; practical teaching; teaching reform; innovation and entrepreneurship ability

\section{INTRODUCTION}

The State Council issued the opinions on several policies and measures to vigorously promote mass entrepreneurship and innovation. Ministry of Education of China issued opinions on vigorously promoting innovation and entrepreneurship education and independent entrepreneurship in colleges and universities. The cultivation of innovation and entrepreneurship ability has become one of the important goals of talent cultivation in colleges and universities. The outline of the national medium - and longterm educational reform and development (2010-2020) also clearly points out: "improve the cultivation mode of ability first, constantly strengthen social practice activities, and gradually improve students' innovative thinking and ability".

The specialty of economics and management majors is closely combined with social practice, and practice is an

*Fund: This study is funded by youth academic innovation team of management science and engineering of SUPL. important part of talent training of these majors. At present, in the course of cultivating economic and management talents in colleges and universities, the emphasis on theory over practice, knowledge imparting over ability cultivation are still prevalent. This makes it difficult for graduates majoring in economics and management to meet the demand of employers for job skills. Therefore, it has become very necessary and urgent to update and adjust the practical teaching system of economics and management majors with the improvement of innovation and entrepreneurship ability as the orientation.

\section{BACKGROUND OF REFORM OF PRACTICAL TEACHING SYSTEM FOR ECONOMICS AND MANAGEMENT MAJORS}

\section{A. The Contradiction Between Economic and Social}

Development's Demand for Economics and Management Talents and the Existing Educational Mode

Since the reform and opening up, China's GDP has grown by more than $8 \%$ for more than 30 years, and the national economy has made great progress. With the continuous improvement of China's market economy, all kinds of employers have an unprecedented expansion of demand for graduates majoring in economics and management. However, graduates of economics and management major are not strong in practical ability, lack adequate methods to solve practical problems, and generally have poor adaptability, which is often difficult to meet the expectations of employers. This is because the traditional teaching mode of economics and management majors, which is mainly based on classroom teaching, makes students accustomed to accept ready-made conclusions, but not good at analyzing and solving problems. Therefore, under the social background of mass innovation and entrepreneurship, the fundamental requirement of the reform of practical teaching system of economics and management majors is to promote students' understanding and contact with practical work, so as to cultivate application-oriented economic and management talents with innovative ability, entrepreneurial ability and wide adaptability. 


\section{B. Urgent Requirements for the Value Embodiment of Economics and Management Disciplines}

Economics and management are not purely technical subjects, but a kind of outstanding studies closely related to real life. The value of economics and management disciplines needs to be reflected by solving problems in social development, and the effect of their work is closely related to the practical abilities of practitioners such as organization, coordination and communication. The comprehensive quality of the graduates of the economics and management majors cultivated by the traditional classroom teaching mode is far from the requirements of the society, and they cannot effectively reflect the value of economics and management majors. To change this situation, we need to fully consider the characteristics of the jobs that the graduates of economics and management majors are engaged in. To be specific, it is necessary to reform the practical teaching system based on innovation and entrepreneurship ability, simulate the social and economic environment on campus as much as possible, and train students' practical ability in an all-round way. Therefore, to build a multi-level, three-dimensional and modular practical teaching system is an urgent requirement to fully reflect the value of economics and management disciplines, which needs to be guided by the cultivation of innovation and entrepreneurship ability.

\section{Internal Demand for Improving Practical Teaching Effect of Economics and Management Majors}

The development of internet, cloud computing and other technologies has provided good opportunities for the improvement of practical teaching effect of economics and management majors, and also brought some challenges. Experimental projects have not formed distinct features, practical teaching has been regarded as a subsidiary link of theoretical teaching, and practical courses have not been planned separately, which results in a great reduction of practical teaching effect of economics and management majors. In fact, practice teaching system is a unique teaching mode different from theory teaching. The laboratory resources, the hardware and software matching, the teacherstudent interaction pattern and so on have their own characteristics, and the practice teaching must match with these characteristics. Therefore, to improve the effect of practical teaching of economics and management majors, we should pay attention to the unique law of practical teaching and strengthen the coupling of practical teaching method and modern educational technology.

\section{Main PROBlems IN PRACTICAL TEACHING OF ECONOMICS AND MANAGEMENT MAJORS}

For a long time, the practical teaching ideas, contents and methods of economics and management majors in Chinese universities have been seriously disconnected from the new theories and technologies that have been developing rapidly. Practical teaching has become a weak link in the teaching process of economics and management majors, which seriously restricts the cultivation of students' innovation and entrepreneurship ability.

\section{A. Being Out of Touch in Practical Teaching and Theoretical Teaching}

In recent years, the theoretical teaching system of economics and management majors has been adjusted with the development of social economy, and the practical teaching system should be updated accordingly. Due to the shackles of traditional teaching concepts, the practice teaching of economics and management majors generally emphasizes the teaching of theoretical knowledge and ignores the cultivation of ability. At the same time, due to the lack of practical skills of teachers of economics and management majors, the establishment of practical teaching projects and teaching programs of various courses is different from the goal of ability cultivation. Many teachers still follow the tradition of implantable teaching, and it is difficult to achieve the goal of cultivating students' problemsolving ability through practice and simulation. It is difficult for the graduates of economics and management majors cultivated by traditional teaching mode to form comprehensive professional quality and ability. After they go to work, it is difficult for them to adapt to the requirements of employers, which makes the practical teaching system of economics and management majors less effective.

\section{B. Lack of Systematic and Innovative in Practice Teaching Research}

The practical teaching of economics and management is not only in the subordinate and marginal position in daily teaching, but also receives less attention in the field of teaching research. Due to the restriction of ideology, fund input, teaching resources and other aspects, the single and confirmatory experiment occupies the main body of practical teaching of economics and management majors. However, the lack of comprehensive and experiential practical teaching projects leads to the low level and systematic deficiency of practical teaching in economics and management majors. This kind of shallow and low - end experimental mode leads to the passivity of teachers and students in the process of practice. This mode has great constraints on students' creativity, which is not conducive to the training of students' thinking ability and innovation and entrepreneurship ability.

\section{Backward Practice Teaching Management Mode and Low-end Teaching Quality Control}

In addition to a few finance universities and comprehensive universities featured by economics and management majors, many universities lag behind in the overall planning, funding input and quality management of the practical teaching system of economics and management major. Teachers' efforts and achievements in guiding students to carry out practical activities are not recognized properly. Under the restriction of undergraduate teaching level evaluation of the ministry of education, universities have generally formed a relatively complete teaching operation and quality control index system in theory teaching. In contrast, due to the lack of clear and reasonable standards, the quality control of practical teaching in economics and management majors is in a hollow form, and the effect of practical teaching is greatly affected. 


\section{Imperfect Practice Teaching Guarantee and Formalized Practice Base Construction}

Many universities do not invest enough funds in economics and management majors, which lead to the failure to update the experimental equipment timely. Experimental teaching materials are lack of pertinence and practicability, and can't reach the expected effect of practical teaching. Limited by factors such as capital investment and teaching space, practical courses of economics and management majors are mainly offered by simulation in the laboratory. There is still a certain distance between this practical course and the real operation of the front-line market, and the authenticity of students' experience and training effect is greatly compromised. As a result, the construction of practice teaching base outside the school has become an important means to bridge the gap. However, due to unclear positioning, poor communication, lack of reciprocity mechanism, improper management and other reasons, the construction of off-campus practice bases for most economics and management majors has become political achievements projects. The construction of off-campus practice bases is formalized and can't play its due role in talent cultivation.

\section{OBJECTIVES AND IDEAS OF PRACTICAL TEACHING SYSTEM REFORM OF ECONOMICS AND MANAGEMENT MAJORS}

\section{A. Objectives of the Reform of Practical Teaching System of Economics and Management Majors}

The reform of practical teaching system of economics and management majors should be guided by the demand of society and market for applied talents of economics and management. This reform should take cultivating students' innovative consciousness and entrepreneurial ability as the main line, integrate the existing software and hardware resources, and explore a new mode of practical teaching for economics and management majors. Specifically, the new training mode should take the cultivation of the spirit of innovation and entrepreneurship as the overall goal and build students' practical ability as the central link. The new training mode is to build an experimental platform for innovation and entrepreneurship, which is closely connected with economic and social development and oriented to the training of application-oriented economic and management personnel. The practical courses offered by the economics and management majors are no longer only dependent on theoretical teaching, but have both professional characteristics and practical spirit. It has developed into a complete set of practical teaching system, and can be forward-looking and experiential.

\section{B. Ideas for Reform of Practical Teaching System of Economics and Management Majors}

1) Defining the value of practical teaching for the cultivation of economics and management talents: The discipline attribute of economics and management majors is comprehensive application, which emphasizes coming from practice and going to practice to realize the close combination of theory and practice. The majors of economics and management should be devoted to cultivating students' ability to analyze and solve problems, so as to put what they have learned into practice. At the present stage, it has become a common understanding for economics and management majors to cultivate skilled and applied talents with strong practical ability who meet the needs of economic and social development. Therefore, in the teaching process of economics and management majors, we should strengthen the complementarity and interaction between theory teaching and practice teaching, and actively create conditions for students to participate fully. This practice can not only improve students' practical ability and problem analysis ability, but also help cultivate their innovation and entrepreneurship ability.

2) Promoting the reform of practical teaching by setting up comprehensive practical courses across various majors: It is needed to o expand the comprehensive practical courses of different majors, that is, to absorb the essence of other majors on the basis of the practical courses of this major, and to develop compound and crossover practical courses. The practical course system of economics and management major should be changed from single, static and scattered experiment to comprehensive and crossing experiment. This will gradually form a compound, comprehensive, practical teaching system. Among them, comprehensive practice courses across different majors should be mainly based on simulation, skill training and subject competition. In addition, the practice of innovation and entrepreneurship should focus on school-enterprise cooperation and simulation of company operation. College students take part in the simulation of the specific role in the operation of enterprises. They fully experience the process of enterprise operation and management in the specific activities such as market research, procurement and production, organization and management, so as to improve their operation and management ability.

3) Optimizing experimental teaching resources to improve practical teaching links: Economics and management majors should be guided by the cultivation of innovation and entrepreneurship ability to enrich practical course resources.We need to build a well-structured entrepreneurship curriculum system that integrates entrepreneurship programs, training and simulation. In the entrepreneurial simulation course system, we need to effectively integrate the experimental courses of different majors. In this way, college students can go through the whole process of personnel recruitment, procurement business, production process and sales business. In this way, college students can be really familiar with the actual process of entrepreneurship, and cultivate their business decision-making ability, coordination ability and innovation and entrepreneurship ability. Universities should also expand the category of open practical projects for the majors 
of economics and management, and enhance the exploration and creation ability of college students. Universities need to rely on modern internet technology to increase the development of practical teaching materials, practical projects and other resources, so as to help students use network resources to promote practical learning in their spare time. Universities should build a simulation system based on resources such as laboratories and practical teaching bases. This can provide a platform for college students to combine theory with practice and enhance their immersive experience.

4) Strengthening the reform of teaching management and teaching security: The quality of practice teaching needs to be guaranteed by scientific and reasonable evaluation mechanism. One of the important contents of practical teaching reform for economics and management majors is the reform of practical teaching evaluation mechanism. In the practical teaching management of economics and management majors, universities should focus on strengthening the management and supervision of professional practical teaching, centering on the cultivation of students' innovation and entrepreneurship ability. In order to promote the improvement of practical teaching quality of economics and management majors, universities can introduce the off-campus evaluation into the practical teaching evaluation and construct the university-enterprise cooperative practical teaching evaluation mechanism. The main body of evaluation in the school is composed of practice teaching management center, experimental supervision group, peer teachers and college students. The main body of off-campus evaluation is composed of practice base internship tutors and part-time enterprise teachers from the business community. In terms of teaching evaluation of economics and management majors, universities should form a multi-level and multi-angle practical teaching evaluation system, with front-line personnel of enterprises as the main body for off-campus evaluation. This practice will promote the practical teaching system of economics and management majors to be more in line with the actual situation of enterprises' operation line, and positively promote the effect of practical teaching of economics and management majors.

\section{THE CONSTRUCTION OF PRACTICAL TEACHING SYSTEM OF ECONOMICS AND MANAGEMENT MAJORS FOR CULTIVATING INNOVATION AND ENTREPRENEURSHIP} ABILITY

\section{A. Designing the Practical Curriculum System Guided by the Cultivation of Innovation and Entrepreneurship Ability}

The cultivation of innovation ability of economics and management talents is not only the call of the times, but also the urgent demand of employers. With the cultivation of innovation and entrepreneurship ability as the orientation, the reform idea of practical teaching system of economics and management majors can be put into practice by improving the course system setting. Generally speaking, universities should design the practical course system of economics and management majors according to the demand of economic and social development for economic and management talents. To be specific, universities should design courses according to the logic of "market demand investigation $\rightarrow$ ability standard refinement $\rightarrow$ experimental project development $\rightarrow$ experimental course setting". First of all, universities need to survey the demand of economic and management professionals from cooperative enterprises, employment departments and other institutions through surveys, interviews, literature reasoning and other means. After identifying the needs of many employers for application-oriented economics and management talents, universities can extract the standards of talents according to their needs, and further sort out the indicators of innovation and entrepreneurship ability. Then, according to teaching software, teachers' expertise, experimental resources and other conditions, universities can design experimental projects that match the cultivation of college students' ability, and then combine several experimental projects according to certain internal logic to form experimental courses.

\section{B. Special Planning and Independent Setting of Practical Training Courses}

In the aspect of cultivating college students' innovation and entrepreneurship ability, practice teaching and theory teaching are complementary means. At present, due to the limitations of educational philosophy, teachers' quality and experimental resources, many practical links exist as supplementary forms of theoretical courses. Compared with the traditional pure theory teaching mode, although this has been a great progress, there are still problems such as insufficient practical class hours, low participation of students and poor practical teaching effect. In order to effectively improve the quality of practical teaching and avoid theoretical teaching crowding out the time and space of practical teaching, it is necessary to ensure the special planning and independent setting of practical courses through clear system design. In this way, it can play a leading role in cultivating students' innovation and entrepreneurship ability. Through the phased and modular construction, colleges and universities have gradually built a practical teaching system that is parallel to and organically integrated with theoretical teaching, and a typical "twosystem" pattern has been formed in the talent training program for economics and management majors.

\section{Building a Multi-level and Three-dimensional Platform System for Practical Courses}

According to the knowledge and ability structure requirements of college students at different learning stages, universities should gradually build a multi-level, threedimensional and modular experimental course platform system. This course platform system is composed of basic experiment of economics and management, major basic experiment, comprehensive cross-major experiment and innovation and entrepreneurship experiment. The basic experiment of economics and management disciplines is 
mainly for the junior students. The purpose of this kind of experiment is to help college students form an intuitive understanding of macro-economy and business management. This kind of course system includes market research and social statistics. Major basic experiments are mainly aimed at the unique needs of various majors for talent cultivation. This kind of experiment is mainly aimed at junior college students. For example, finance major offers practical courses such as securities investment practice. Comprehensive crossmajor experiment integrates the relatively independent and separate majors, and constitutes a new practice teaching system that integrates organically and promotes each other. This kind of experiment is mainly aimed at senior college students to improve their comprehensive and in-depth understanding of the operation of national economy and enterprise management. The main appeal of the innovation and entrepreneurship experiment course is to directly improve the innovation and entrepreneurship ability of college students. On the basis of defining the main occupational post groups of college students' employment, this part of courses is closely combined with the ability requirements of occupational post groups. The experimental contents mainly include quality development courses, school-enterprise cooperation courses, vocational skills competitions and other forms.

\section{Constructing a School-enterprise Combination Teaching Model of Innovation and Entrepreneurship Practice}

The talents cultivated by economics and management majors are closely combined with social and economic development. School-enterprise cooperation is an important way to improve the practical teaching effect of economics and management majors. The depth and mode of schoolenterprise cooperation have an important influence on the quality of talent cultivation of economic management majors. School-enterprise cooperation should combine simulation with actual combat organically, and explore the establishment of entrepreneurship training companies with practical operation of college students as the main body. With the support and cooperation of the university and cooperative enterprises, universities has set up a number of entrepreneurship training companies, which are mainly held by teachers majoring in economics and management and college students, to carry out entrepreneurship activities independently. Under this model, students majoring in economics and management can simulate specific business roles of enterprises. College students are specifically engaged in business decision-making, management, production, marketing and other operational activities, and practice what they have learned in the front line of social economy, so as to obtain good learning results. Therefore, entrepreneurship training company is a frontier form to improve the innovation and entrepreneurship ability of college students. Entrepreneurship training company integrates relevant resources inside and outside the university and provides a new carrier for college students to start their own business. Entrepreneurial training companies can realize the transformation from system simulation to full practice training.

\section{CONCLUSION}

The majors of economics and management in universities require a strong demand on the practical ability of college students. The goal of these majors is to cultivate interdisciplinary and applied talents with knowledge and ability of economy, management, law and decision-making, which can meet the needs of economics and management work and have innovative ability. However, due to the longterm influence of traditional educational theories, teaching methods and talent cultivation models, the education of economics and management majors in Chinese universities generally has the tendency of emphasizing knowledge over ability, theory over practice, and uniformity over individual development, thus overemphasizing knowledge imparting. Practical teaching is placed in the secondary position, and has been ignored for a long time. As a result, the graduates are generally lack of practical ability and the ability to adapt to society, so that they cannot meet the requirements of cultivating complex, application-oriented and innovative talents. Therefore, universities need to actively promote the reform of practical teaching of economics and management majors, explore new ideas of practical teaching, so as to build and improve the new practical teaching system. This is particularly important to improve the quality of practical teaching, especially to improve the quality of personnel training.

Practical teaching refers to a series of teaching activities in which students acquire perceptual knowledge and basic skills through practical operation under the guidance of teachers. Practice teaching is an important part of university teaching activities, which are the verification, supplement and expansion of theoretical teaching. It has the characteristics of directness, practicality, exploration and inspiration. It plays a special role in improving students comprehensive quality, cultivating their innovative spirit and practical ability. Under the background of the state vigorously promoting innovation and entrepreneurship education, the cultivation of innovation and entrepreneurship ability has become one of the important goals of talents cultivation in universities, especially in the field of economics and management majors. Guided by the improvement of college students' innovation and entrepreneurship ability, this study discusses the reform of practical teaching system of economics and management majors from the perspectives of background, problems, goals and ideas. This study puts forward specific reform suggestions from the aspects of practice system, curriculum planning, and platform system and school-enterprise cooperation.

\section{REFERENCES}

[1] Zhang Y C. Research on the construction of university economic management laboratory under the characteristics of the new era [J].Rural economy and technology, vol.34, pp.289-290, April 2019.

[2] Wang H L, Geng X W, Shao H Q. Reform and practice of practical teaching model in universities based on "entrepreneurship and innovation" training [J]. Journal of higher education, vol.97, pp.53-55, January 2019. 
[3] Jiang L. Construction of practical teaching quality monitoring system for economics and management majors in application-oriented universities [J]. Jiangsu science and technology information, vol.36, pp.57-59, March 2019

[4] Chen R, Zhang M.Research on teaching reform of economics and management majors in the era of big data $[\mathrm{J}]$. Information recording materials, vol.20, pp.142-143, January 2019

[5] Wang H L. On the improvement of maker education in Chinese universities [J]. Journal of fuzhou university, vol.32, pp.104-108, February 2018.

[6] Wang D, Li P, Wang Z T. Research on construction of "1+3" course assessment mode for economics and management majors in applied universities [J]. Journal of suihua university, vol.38, pp.130-132, May 2018

[7] Yao L, Xi S, Yi L, et al. The teaching system reformation of economics and management in independent colleges[J]. Private Education Research, vol.40, pp.847-849, December 2017.

[8] Xue Y J, Chen J C, Wang M L. Exploration and practice of virtual simulation experiment teaching for economics and management majors [J].Laboratory research and exploration, vol.36, pp.290-293, October 2017.

[9] Fawson C, Simmons R, Yonk R. Curricular and programmatic innovation at the intersection of business ethics and entrepreneurship $[J]$. Advances in the Study of Entrepreneurship Innovation \& Economic Growth, vol.25, pp.109-130, April 2017

[10] Wang S, Zhang Q, Cai X. Multiple practice teaching reform of economics [J]. Journal of Graphics, vol.38, pp.453-457, March 2017.

[11] Chen S, Yang C. Difficulties and solutions of the teaching reform of the undergraduate major of economics and management in local universities [J]. Journal of tangshan university, vol.29, pp.106-108, February 2016.

[12] Hechavarria D M, Welter, Chris. Opportunity types, social entrepreneurship and innovation: Evidence from the panel study of entrepreneurial dynamics $[\mathrm{J}]$. International Journal of Entrepreneurship \& Innovation, vol.6, pp.1-6, Apirl 2015.

[13] Priem R L, Li, S, Carr, J. C. Insights and new directions from demand-side approaches to technology innovation, entrepreneurship, and strategic management research [J]. Journal of Management, vol.38, pp.346-374, January 2012.

[14] Sun H. The 3-3-3 framework and 7P model for teaching creativity, innovation and entrepreneurship [J]. IEEE Engineering Management Review, vol.40, pp.157-163, February, 2012.

[15] Washburn N R. Teaching innovation and entrepreneurship: building on the Singapore experiment [J]. Cambridge University Press, vol.16, pp.3-1-315, March, 2009.

[16] Graevenitz G V, Dietmar Harhoff, Richard Weber. The effects of entrepreneurship education [J]. Journal of Economic Behavior \& Organization, vol.76, pp.90-112, January 2010.

[17] Ran Z. Exploration on the key issues of practical teaching reform of computer network [J]. Energy Procedia, vol.17, pp.1914-1919, February, 2012.

[18] Yang Z. The teaching reform of managerial economics [J]. Advanced Materials Research, vol.6, pp.271-273, June 2011.

[19] Velzen C V, Monique Volman, Mieke Brekelmans. Guided workbased learning: Sharing practical teaching knowledge with student teachers [J]. Teaching \& Teacher Education, vol.28, pp.229-239, February, 2012.

[20] Emery C R, Tian, Robert G. Schoolwork as products, professors as customers:a practical teaching approach in business education[J]. Journal of Education for Business,vol.78, pp.97-102, February,2002.

[21] Irby D M. Practical teaching: great presentations every time [J]. Clinical Teacher, vol.18, pp.5-9, January, 2010.

[22] Cui Y. Construction of experimental platform for innovation and entrepreneurship of economics and management majors under the background of transformation of ordinary universities [J]. Statistics and management, vol.18, pp.160-161, May 2015.

[23] Li Y. Experimental teaching research with innovation and entrepreneurship ability as the training target — taking economics and management major as an example [J]. Inner Mongolia education, vol.23, pp.83-84, May 2015.

[24] Luo Y. Based on the "six combinations" construction of experimental teaching platform for economics and management[J].Modern education technology, vol.22, pp.112-115, September 2012.

[25] Dang J, Dong Y. Construction of experimental teaching system for economics and management based on professional ability improvement $[\mathrm{J}]$. Journal of northwest university for nationalities (philosophy and social sciences edition), vol.13, pp.182-188, March 2012 .

[26] Niu H, Zhang B G, Dong J G. Exploration on experimental practice teaching reform of economics and management majors oriented by cultivation of innovation ability $[\mathrm{J}]$. Laboratory science, vol.15, pp.28-31, January, 2012. 